\title{
Cytoprotective Constituents of the Heartwood of Caesalpinia sappan on Glutamate-Induced Oxidative Damage in HT22 Cells
}

\author{
Gil-Saeng Jeong, ${ }^{a}$ Dong-Sung Lee, ${ }^{b}$ Tae-Oh Kwon,${ }^{c}$ Hye-Suk Lee, ${ }^{d}$ Ren-Bo An, ${ }^{*, e}$ and \\ Youn-Chul $\mathrm{KIM}^{*, b}$ \\ ${ }^{a}$ Institute of Radiological Imaging Science, Wonkwang University; ${ }^{b}$ College of Pharmacy, Wonkwang University; ${ }^{c}$ College \\ of Life Science and Natural Resources, Wonkwang University; 'Drug Metabolism and Bioanalysis Laboratory, College of \\ Pharmacy, Wonkwang University; Iksan 570-749, Korea: and ${ }^{e}$ Key Laboratory of Organism Functional Factors of the \\ Changbai Mountain, College of Pharmacy, Yanbian University; Yanji 133002, Jilin Province, P.R. China.
}

Received January 22, 2009; accepted February 18, 2009; published online February 20, 2009

\begin{abstract}
The bioassay-guided fractionation of a MeOH extract of the heartwood of Caesalpinia sappan L. provided two neuroprotective compounds, sappanchalcone (2) and 4- $O$-methylepisappanol (3), together with a methoxychalcone, isoliquiritigenin 2 '-methyl ether (1), and three aromatic compounds, 4- $O$-methylsappanol (4), caesalpine $J$ (5), pluchoic acid (6). At concentrations of $20-40 \mu \mathrm{M}$, compound 2 showed significant cytoprotective effects against glutamate-induced oxidative stress through the induction of heme oxygenase (HO)-1 in HT22immortalized hippocampal cells. Compound 3 also showed moderate neuroprotective effect at $40 \mu_{\mathrm{M}}$, but compounds 1, 4-6 did not show any protective effects against glutamate-induced cytotoxicity in HT22 cells.
\end{abstract}

Key words Caesalpinia sappan; neuroprotective; glutamate; HT22 cell; heme oxygenase-1

The heartwood of Caesalpinia sappan L. (Leguminosae), Sappan Lignum, has been used in oriental medicine to promote blood circulation. Its various pharmacological properties such as analgesic, anti-inflammatory, ${ }^{1,2)}$ anti-complementary, ${ }^{3)}$ antifungal, ${ }^{4}$ antioxidative, ${ }^{5)}$ and antimicrobial activities have already been reported. ${ }^{6}$ ) As the principal component, homoisoflavonoids have previously been isolated from the heartwood of C. sappan. ${ }^{7)}$

Neuronal cell toxicity occurs when there is an imbalance in the systems that generate and scavenge reactive oxygen species (ROS) in a variety of pathological processes, including ischemia-reperfusion injury and neurodegenerative disease. ${ }^{8,9)}$ Glutamate is well-known as a critical contributor to pathological neuronal cell death within the nervous system. ${ }^{10,11)}$ Glutamate also causes oxidative injury by suppressing the cellular uptake of cysteine via the cysteine/glutamate transport system, which causes a progressive depletion of glutathione. ${ }^{12,13)}$

HT22 cells, originating from the mouse hippocampus, have been used as a valuable model for studying the mechanism of glutamate-induced neuronal cytotoxicity. This cell line lacks the functional ionotropic glutamate receptors, thereby excluding excitotoxicity as a cause for glutamatetriggered cell death. ${ }^{9,11)}$ Furthermore, among the three isozymes, heme oxygenase (HO)-1, HO-2 and $\mathrm{HO}-3$, (HO)1 , plays a critical role in the cellular defense system against glutamate-induced oxidative damage in HT22 cells. ${ }^{12}$

As a part of our continuing research to identify medicinal plant substances that can protect HT22 cells, ${ }^{14,15)}$ we isolated six compounds including two neurocytoprotective compounds from the heartwood of $C$. sappan that showed protective activity against glutamate-induced oxidative cellular damage in HT22 cells. In addition, we demonstrate that one of the isolated compounds, sappanchalcone (2), increases cellular resistance to oxidative injury caused by glutamateinduced cytotoxicity in HT22 cells, through nuclear factor E2-related factor 2 (Nrf)2-dependent HO-1 expression and via activation of the p38 mitogen-activated protein kinase
(MAPK) pathway.

\section{MATERIALS AND METHODS}

Materials Dulbecco's modified Eagle's medium (DMEM), fetal bovine serum (FBS), and other tissue culture reagents were purchased from Gibco BRL Co. Tin protoporphyrin IX (SnPP IX), an inhibitor of HO activity, was obtained from Porphyrin Products. All other chemicals were obtained from Sigma Chemical Co., unless indicated otherwise. Mouse hippocampal HT22 cells were obtained from Dr. Inhee-Mook (Seoul National University, Korea). The cells were maintained at $5 \times 10^{5}$ cells $/ \mathrm{ml}$ in DMEM medium supplemented with $10 \%$ heat-inactivated FBS, penicillin G (100 units $/ \mathrm{ml})$, streptomycin $(100 \mathrm{mg} / \mathrm{ml})$, and L-glutamine ( $2 \mathrm{~mm}$ ) and incubated at $37^{\circ} \mathrm{C}$ in a humidified atmosphere containing $5 \% \mathrm{CO}_{2}$ and $95 \%$ air. The heartwood of C. sappan was purchased from the University Oriental Drugstore, Iksan, Korea in July 2007. A voucher specimen (No. WP07296) was deposited at the Herbarium of the College of Pharmacy, Wonkwang University (Korea).

General Experimental Procedures Melting points were determined using a Yanaco MP-S3 micro melting point apparatus and the values presented are not corrected. Optical rotations were measured on a JASCO P-1020 polarimeter. UV spectra were obtained on a Shimadzu UV-1601 UV-visible spectrometer. The NMR spectra were recorded on a JEOL Eclipse-500 $\mathrm{MHz}$ spectrometer $\left(500 \mathrm{MHz}\right.$ for ${ }^{1} \mathrm{H}$ and $125 \mathrm{MHz}$ for ${ }^{13} \mathrm{C}$ ), and chemical shifts are quoted versus tetramethylsilane. ESI-MS was obtained on a Quattro LCMS (Micromass).

Extraction and Isolation Dried heartwood C. sappan $(2 \mathrm{~kg}$ ) was extracted twice with hot $\mathrm{MeOH}(10 \mathrm{l})$ for $2 \mathrm{~h}$. The $\mathrm{MeOH}$ extract (49.3 g) was dissolved in $60 \%$ aqueous $\mathrm{MeOH}$ and partitioned with $n$-hexane $(2 \times 11)$, followed by $\mathrm{CHCl}_{3}$ $(2 \times 11)$. The $60 \%$ aqueous $\mathrm{MeOH}$ layer was evaporated in vасио, and the resulting residue was dissolved in water and successively partitioned with EtOAc $(2 \times 11)$ and $n$-BuOH 
$(2 \times 11)$. The EtOAc-soluble fraction $(25.7 \mathrm{~g})$ was chromatographed on a silica gel column $(6.5 \times 60 \mathrm{~cm})$ using $\mathrm{CH}_{2} \mathrm{Cl}_{2} / \mathrm{MeOH}(20: 1-1: 1, \mathrm{MeOH}$, each 11$)$ as the eluent to obtain six fractions (Fr. A-F). Fr. A $(603.5 \mathrm{mg})$ was chromatographed on a reverse-phase (YMC Gel ODS-A, S$75 \mu \mathrm{m})$ column $(3 \times 25 \mathrm{~cm})$ eluted with $50 \%$ aqueous $\mathrm{MeOH}$ to yield five fractions (Fr. A1-A5). Fr. A4 (39.7 mg) was subjected to silica gel column chromatography with $n$ hexane/EtOAc $(2: 1)$ to give compound 1 (14.0 mg). Fr. B $(2.8 \mathrm{~g})$ was chromatographed on an ODS-A column $\left(3 \times 30 \mathrm{~cm}, \mathrm{MeOH} / \mathrm{H}_{2} \mathrm{O}, 1: 1.5\right)$ to yield five sub-fractions (Fr. B1-B5). Fr. B4 $(578.7 \mathrm{mg})$ was repeatedly chromatographed on a silica gel column $(2 \times 30 \mathrm{~cm}$, eluent; $n$ hexane/EtOAc, 2:1) and reverse-phase MPLC (column: ODS-S-50 B, $120 \AA, 50 \mu \mathrm{m})$ to give compound $2(69.2 \mathrm{mg}$ ) and 3 (15.0 mg). Fr. D (4.08 g) was subjected to silica gel column $(2 \times 30 \mathrm{~cm})$ chromatography (eluent; $\mathrm{CH}_{2} \mathrm{Cl}_{2} / \mathrm{MeOH}$, $4: 1)$ to yield four sub-fractions (Fr. D1-D4). Fr. D1 (442.1 mg) was subjected to an ODS-A column $(2 \times 30 \mathrm{~cm})$ chromatography (eluent; 65\% aqueous $\mathrm{MeOH}$ ) to obtain compound 4 (82.8 $\mathrm{mg})$.

The $\mathrm{CHCl}_{3}$ soluble fraction $(5.0 \mathrm{~g})$ was subjected to column chromatography on a Sephadex LH-20 column (eluent; $\mathrm{CH}_{2} \mathrm{Cl}_{2} / \mathrm{MeOH}, 4: 1$ ) to afford six fractions (Fr. G-L). Fr. K $(1.3 \mathrm{~g})$ was subjected to silica gel column $(2 \times 30 \mathrm{~cm})$ chromatography (eluent; $\mathrm{CH}_{2} \mathrm{Cl}_{2} / \mathrm{MeOH}, 17: 1$ ) to obtain five sub-fractions (Fr. K1-K5). Fr. K4 (305.3 mg) was repeatedly chromatographed on an ODS-A column $(3 \times 30 \mathrm{~cm}$, $\mathrm{MeOH} / \mathrm{H}_{2} \mathrm{O}, 1: 3$ ) and Sephadex LH-20 column (eluent: $\left.\mathrm{CH}_{2} \mathrm{Cl}_{2} / \mathrm{MeOH}, 15: 1\right)$ to give compound $5(96.1 \mathrm{mg})$ and 6 (12.1 mg).

Cell Viability Assay For determination of cell viability, $50 \mathrm{mg} / \mathrm{ml}$ of 3-[4,5-dimethylthiazol-2-yl]-2,5-diphenyltetrazolium bromide (MTT) was added to $1 \mathrm{ml}$ of cell suspension $\left(1 \times 10^{5}\right.$ cells $/ \mathrm{ml}$ in 96 -well plates) and incubated for $4 \mathrm{~h}$. The formazan formed was dissolved in acidic 2-propanol; optical density was measured at $590 \mathrm{~nm}$. The optical density of formazan formed in control (untreated) cells was taken as $100 \%$ viability.

Preparation of Nuclear and Cytosolic Fractions Cells were homogenized $(1: 20, \mathrm{w} / \mathrm{v})$ in PER-Mammalian Protein Extraction buffer (Pierce Biotechnology, Rockford, IL, U.S.A.) containing freshly-added protease inhibitor cocktail I (EMD Biosciences, San Diego, CA, U.S.A.) and $1 \mathrm{~mm}$ phenylmethylsulfonyl fluoride (PMSF). The cytosolic fraction of the cell was prepared by centrifugation at $15000 \times \mathbf{g}$ for $10 \mathrm{~min}$ at $4{ }^{\circ} \mathrm{C}$. Nuclear and cytoplasmic extracts of HT22 cells were prepared, using NE-PER nuclear and cytoplasmic extraction reagents (Pierce Biotechnology). After treatment, HT22 cells $\left(3 \times 10^{6}\right.$ cells $/ 3 \mathrm{ml}$ in $60 \mathrm{~mm}$ dish) were collected and washed with phosphate-buffered saline (PBS). After centrifugation, cell lysis was performed at $4{ }^{\circ} \mathrm{C}$ by vigorous shaking for $15 \mathrm{~min}$ in radio immunoprecipitation assay (RIPA) buffer [150 mm NaCl, 1\% NP-40, 0.5\% sodium deoxycholate, $0.1 \%$ sodium dodecyl sulphate (SDS), $50 \mathrm{~mm}$ Tris- $\mathrm{HCl}$ ( $\mathrm{pH} 7.4), 50 \mathrm{~mm}$ glycerophosphate, $20 \mathrm{~mm} \mathrm{NaF}$, $20 \mathrm{~mm}$ ethylene glycol tetraacetic acid (EGTA), $1 \mathrm{~mm}$ dithiothreitol (DTT), $1 \mathrm{~mm} \mathrm{Na} \mathrm{VO}_{4}$, and protease inhibitors]. After centrifugation at $14800 \times \boldsymbol{g}$ for $15 \mathrm{~min}$, the supernatant was separated and stored at $-70{ }^{\circ} \mathrm{C}$ until further use. Protein content was determined using the bicinchoninic acid (BCA) pro- tein assay kit.

Western Blot Analysis The cells were lysed in $20 \mathrm{~mm}$ Tris- $\mathrm{HCl}$ buffer ( $\mathrm{pH} 7.4$ ), containing a protease inhibitor mixture $(0.1 \mathrm{~mm}$ PMSF, $5 \mathrm{mg} / \mathrm{ml}$ aprotinin, $5 \mathrm{mg} / \mathrm{ml}$ pepstatin A, and $1 \mathrm{mg} / \mathrm{ml}$ chymostatin). Protein concentration was determined using the Lowry protein assay kit (P5625; Sigma). An equal amount of protein for each sample was separated by $12 \%$ SDS-polyacrylamide gel electrophoresis (SDSPAGE) and electrophoretically transferred onto a Hybond enhanced chemiluminescence (ECL) nitrocellulose membrane (Biorad). The membrane was blocked with 5\% skim milk and sequentially incubated with primary antibody (Santa Cruz Biotechnology) and horseradish peroxidase-conjugated secondary antibody, followed by ECL detection (Amersham).

HO Activity Assay HO enzyme activity was measured using a method previously described. ${ }^{16)}$ Briefly, microsomes from harvested cells were added to a reaction mixture containing nicotinamide adenine dinucleotide phosphate, biliverdin reductase from rat liver cytosol, and the substrate hemin. The reaction was conducted at $37^{\circ} \mathrm{C}$ in the dark for $1 \mathrm{~h}$ and then terminated by the addition of $1 \mathrm{ml}$ of chloroform. The extracted bilirubin was calculated by measuring the difference in absorbance between 464 and $530 \mathrm{~nm}$.

ROS Measurement HT22 cells $\left(2.5 \times 10^{4}\right.$ cells $/ \mathrm{ml}$ in $24-$ well plates) were treated with $5 \mathrm{~mm}$ glutamate in the presence or absence of test compounds or SnPP (HO inhibitor) and incubated for $8 \mathrm{~h}$. After washing with PBS, the cells were stained with $10 \mu \mathrm{M} 2^{\prime}, 7^{\prime}$-dichlorofluorescein diacetate (DCFDA) in Hanks' balanced salt solution for $30 \mathrm{~min}$ in the dark. The cells were then washed twice with PBS and extracted with $1 \%$ Triton $\mathrm{X}-100$ in PBS for $10 \mathrm{~min}$ at $37^{\circ} \mathrm{C}$. Fluorescence was recorded with an excitation wavelength of $490 \mathrm{~nm}$ and an emission wavelength of $525 \mathrm{~nm}$ (Spectramax Gemini XS; Molecular Devices, Sunnyvale, CA, U.S.A.).

Statistical Analysis Data are expressed as mean \pm S.D. of at least three independent experiments. To compare three or more groups, one-way analysis of variance (ANOVA) followed by Newman-Keuls post hoc test was used. Statistical analysis was performed with GraphPad Prism software, version 3.03 (GraphPad Software Inc., San Diego, CA, U.S.A.).

\section{RESULTS AND DISCUSSION}

In the present study, we investigated the $\mathrm{MeOH}$ extract of the heartwood of $C$. sappan with aim of identifying natural neuroprotective compounds. Of the $\mathrm{MeOH}$ extract fractions obtained during the course of the study, the EtOAc-soluble fraction and the $\mathrm{CHCl}_{3}$-soluble fraction were found to exert protective effects on HT22 cells treated with glutamate (protective ratio: $83.2 \%$ and $67.1 \%$ at $100 \mu \mathrm{g} / \mathrm{ml}$, respectively). The subsequent bioassay-guided fractionation of these fractions led to the isolation of six compounds. The structures of the isolated compounds were identified as isoliquiritigenin $2^{\prime}$-methyl ether (1), ${ }^{17)}$ sappanchalcone $(2),{ }^{18)}$ 4-O-methylepisappanol (3), ${ }^{19)}$ 4-O-methylsappanol (4), ${ }^{20)}$ caesalpine $\mathrm{J}$ $(5),{ }^{21)}$ and pluchoic acid (6) ${ }^{22)}$ respectively, by comparing $\mathrm{UV},[\alpha]_{\mathrm{D}}, \mathrm{MS},{ }^{1} \mathrm{H}$ - and ${ }^{13} \mathrm{C}-\mathrm{NMR}$ data with literature values (Chart 1).

We first investigated whether the isolated compounds (Chart 1) showed protective effects against glutamate-induced oxidative injury in HT22 cells. Pretreatment of HT22 
<smiles>[R]c1ccc(/C=C/C(=O)c2ccc(O)cc2OC)cc1[R2]</smiles>

$$
\begin{array}{ccc} 
& \mathrm{R}_{1} & \mathrm{R}_{2} \\
\mathbf{1} & \mathrm{OH} & \mathrm{H} \\
\mathbf{2} & \mathrm{OH} & \mathrm{OH}
\end{array}
$$<smiles>CCOC1(O)COC2=CC(=O)C=CC23c2cc(O)c(O)cc2C1C3O</smiles>

5<smiles>[R3][C@]1(O)COc2cc(O)ccc2[C@@]1([R3])Cc1ccc(O)c(O)c1</smiles>

$$
\begin{array}{ccc} 
& \mathrm{R}_{3} & \mathrm{R}_{4} \\
3 & \mathrm{OCH}_{3} & \mathrm{H} \\
4 & \mathrm{H} & \mathrm{OCH}_{3}
\end{array}
$$<smiles>COc1cc(O)ccc1C(=O)O</smiles>

6
Chart 1. The Structures of Compounds $\mathbf{1}-\mathbf{6}$ Isolated from Caesalpinia sappan Heartwood

A

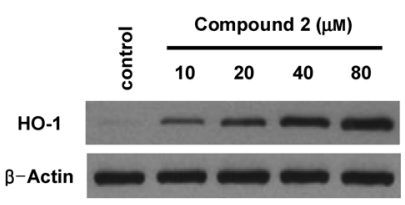

B

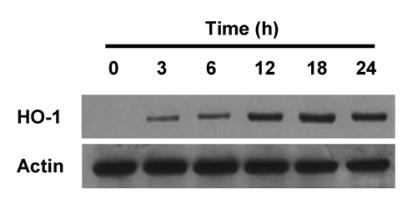

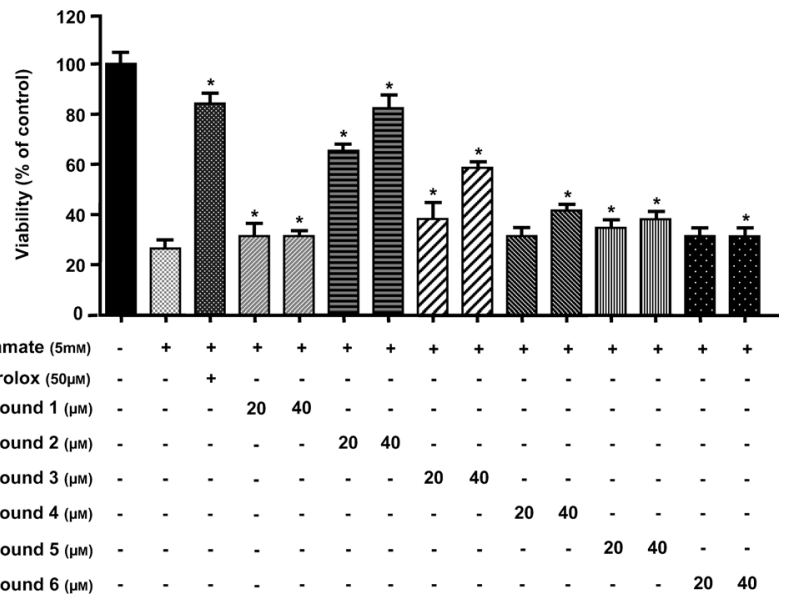

Fig. 1. Protective Effects of Compounds $\mathbf{1}-\mathbf{6}$ on Glutamate-Induced Oxidative Neurotoxicity in HT22 Cells

Cells were treated with compounds $\mathbf{1}-\mathbf{6}$ and then incubated for $12 \mathrm{~h}$ with glutamate $(5 \mathrm{~mm})$. Each bar represents the mean \pm S.D. of three independent experiments. $* p<0.05$ vs. control.
C

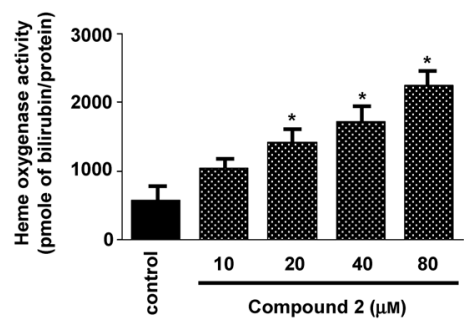

D

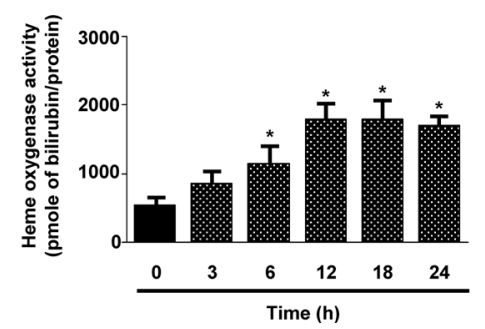

Fig. 2. Effects of Compounds 2 on HO-1 Expression and Activity in HT22 Cells

(A) Cells were incubated with compound 2 for $12 \mathrm{~h}$. (B) Cells were incubated with $80 \mu \mathrm{m}$ of compound 2 for indicated periods. Expression of HO- 1 was determined by Western blot analysis, and representative blots of three independent experiments are shown. (C) HO activity was determined via bilirubin formation at $12 \mathrm{~h}$ after treatment with various concentrations of compound 2. (D) HT22 cells were treated with $80 \mu \mathrm{M}$ of compound 2, and HO activity was measured at the indicated time points. Each bar represents the mean \pm S.D. of three independent experiments. $* p<0.05 v s$. control.

cells with compounds 2 and $\mathbf{3}$, but not $\mathbf{1}, \mathbf{4}-\mathbf{6}$, for $2 \mathrm{~h}$ protected the cells from glutamate-mediated toxicity (Fig. 1). Furthermore, at the range of non-cytotoxic concentrations $(10-80 \mu \mathrm{M})$, we examined whether compounds 2 and $\mathbf{3}$ affected HO-1 protein expression and/or HO activity by treating the HT22 cells with these compounds (Fig. 2). Compound 2 increased HO-1 expression in a concentration- and time-dependent manner and showed the most significant $\mathrm{HO}$ activity at $80 \mu \mathrm{M}$ (Fig. 2). However, compound 3 could neither induce HO-1 protein expression nor exert any $\mathrm{HO}$ activity (data not shown).

In recent studies, HO-1 has been shown to protect against glutamate-induced oxidative damage in HT22 cells. ${ }^{11,23,24)}$ Thus, we tested whether HO-1 expression induced by compound $\mathbf{2}$ mediated any cytoprotective effects. HT22 cells were co-treated with compound 2 for $12 \mathrm{~h}$ in the absence or presence of SnPP, an inhibitor of HO activity (Fig. 3A). SnPP significantly inhibited the protective effect of compound 2. Furthermore, HO-1 expression by compound $\mathbf{2}$ was also required to suppress glutamate-induced ROS generation (Fig. $3 \mathrm{~B})$. In addition, nuclear translocation of activated Nrf2 is an important upstream contributor to the mechanism of HO-1 expression. $^{25)}$ Therefore, we investigated whether treatment of HT22 cells with compound $\mathbf{2}$ induced nuclear translocation of Nrf2. The cells were incubated with compound $\mathbf{2}$ for $0.5,1$ and $1.5 \mathrm{~h}$ at a concentration of $80 \mu \mathrm{M}$, and the nuclear fractions of compound 2-treated cells showed a gradual increase in Nrf2 levels, whereas Nrf2 levels decreased concomitantly in the cytoplasmic fractions (Fig. 4). MAPK is activated in response to oxidative stress and other various stres- 
sors. Several studies have reported that the activation of the MAPK pathways contributes to the induction of HO-1.26,27) Therefore, we examined the effect of compound $\mathbf{2}$ on activation of MAPKs in HT22 cells. Cells were exposed to compound 2, total protein was harvested, and then Western blots were performed using anti-phospho-c-Jun $\mathrm{NH}_{2}$-terminal

A

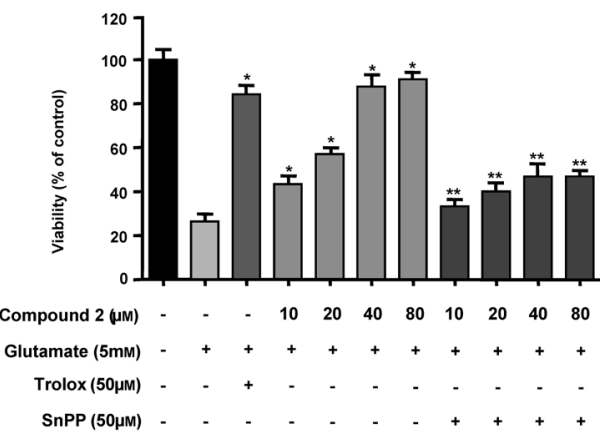

B

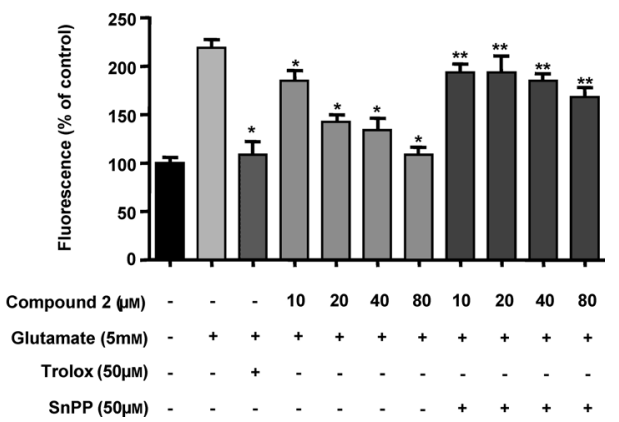

Fig. 3. Effects of HO-1 Induction by Compound $\mathbf{2}$ on Glutamate-Induced Oxidative Neurotoxicity and ROS Generation

(A) Cells were treated with various concentrations of compound 2, 50 $\mu \mathrm{M} \mathrm{SnPP}$ and then exposed to glutamate $(5 \mathrm{~mm})$ for $12 \mathrm{~h}$. Each bar represents the mean \pm S.D. of three independent experiments. $* p<0.05 v s$. glutamate $(5 \mathrm{~mm}), * * p<0.05 v s$. same treat ment plus SnPP. (B) Exposure of HT22 cells to $5 \mathrm{~mm}$ glutamate for $12 \mathrm{~h}$ increased ROS production. Each bar represents the mean \pm S.D. of three independent experiments $* p<0.05 v s$. glutamate $(5 \mathrm{~mm}), * * p<0.05 v s$. same treatment plus SnPP. kinase (JNK), extracellular signal-regulated kinase $1 / 2$ (ERK1/2) and p38 antibodies. At a concentration of $40 \mu \mathrm{M}$, which strongly induced the levels of HO-1, compound $\mathbf{2}$ activated the p38 MAPK pathway and increased p38 MAPK phosphorylation. As shown in Fig. 5A, phosphorylation of ERK was observed 30 min after compound 2 treatment, and was sustained for up to $60 \mathrm{~min}$ after compound 2 treatment. In contrast, phosphorylation of JNK and ERK kinases did not showed at all the tested time periods (Fig. 5A). Furthermore, the p38 MAPK pathway inhibitor (SB203580) significantly reduced compound 2-induced HO-1 expression, while both JNK (SP600125) and ERK1/2 inhibitors (U0126) did not (Fig. 5B). As expected, the p38 MAPK pathway inhibitor abolished compound 2 -induced cytoprotection, but inhibitors of JNK or ERK1/2 pathway did not exert such an effect (Fig. 5C). The p38 inhibitor was not cytotoxic under our experimental conditions (data not shown). However, compound $\mathbf{3}$ possessing a chemical similarity with compound $\mathbf{2}$ did not induce HO-1 expression. We supposed that the moderate cytoprotection by compound $\mathbf{3}$ due to its other antioxidative properties, not induction of HO-1 expression.

Glutamate-induced oxidative damage contributes to neu-

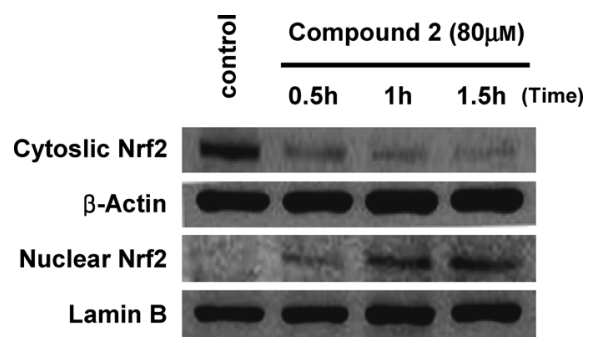

Fig. 4. Effects of Compound $\mathbf{2}$ on Nuclear Translocation of Nrf2

Cells were treated with $80 \mu \mathrm{m}$ of compound 2 for $0.5,1$, and $1.5 \mathrm{~h}$. The nuclei were fractionated from the cytosol using PER-Mammalian Protein Extraction buffer as described in Materials and Methods. Nrf2 protein was detected by Western blot analysis, and representative blots of three independent experiments are shown.
A

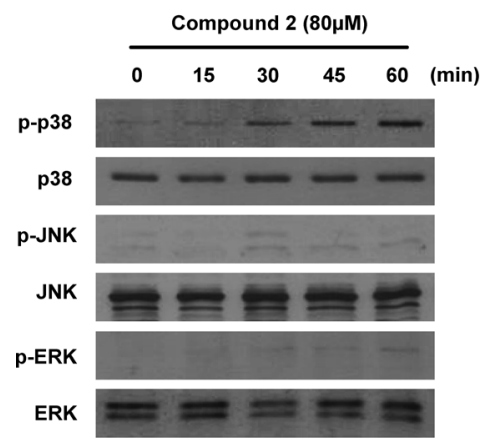

B
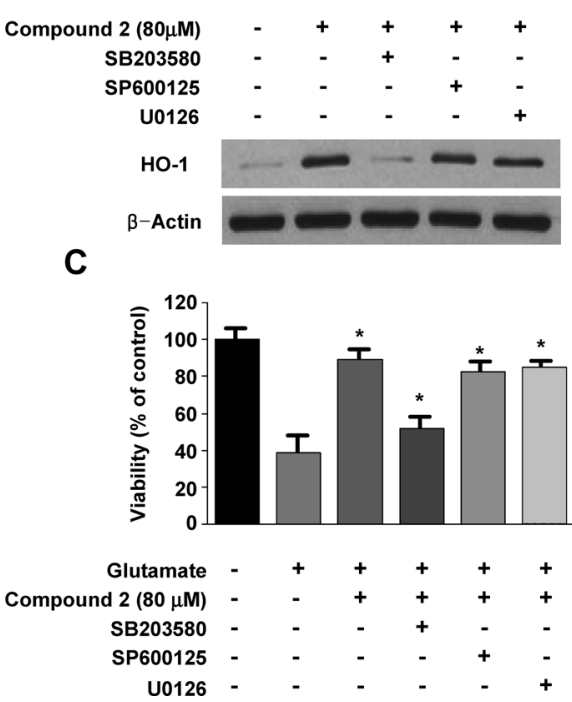

Fig. 5. Effects of Compound 2-Induced p38 MAPK Activation on HO-1 Expression and Glutamate-Induced Neurotoxicity

(A) Cells were treated with $40 \mu \mathrm{M}$ lindenenyl acetate for the indicated times. Cell extracts were analyzed by Western blot with antibodies specific for phosphorylated ERK1/2 (pERK), phosphorylated JNK (p-JNK), or phosphorylated p38 (p-p38). Membranes were stripped and re-probed for total form of each MAPK antibody as a control, and the representative blots of three independent experiments are shown. (B) Cells were incubated with $80 \mu \mathrm{M}$ of compound 2 for $12 \mathrm{~h}$ in the presence or absence of SB203580 ( $20 \mu \mathrm{M})$, SP600125 $(25 \mu \mathrm{M}), \mathrm{U} 0126(10 \mu \mathrm{M})$. Western blotting was then performed with HO-1 antibody. (C) Cells untreated or treated with compound $2(80 \mu \mathrm{M})$ in the presence or absence of each specific inhibitor for $12 \mathrm{~h}$ were exposed to $5 \mathrm{~mm}$ glutamate for $8 \mathrm{~h}$. Each bar represents the mean \pm S.D. of three independent experiments. $* p<0.05 v s$. glutamate $(5 \mathrm{~mm})$. 
ronal degeneration in central nervous system (CNS) diseases such as epilepsy and ischemia. ${ }^{12)}$ In this respect, naturally occurring compounds that have antioxidative properties against glutamate-induced oxidative damage offer a promising strategy for therapeutic applications. HO-1, an important enzyme that contributes to the cytoprotective response, is considered to be an adaptive and protective response against oxidative insult in a wide variety of cells, ${ }^{24,26)}$ including neuronal cells such as HT22. ${ }^{11,27)}$ In addition, nuclear translocation of $\mathrm{Nrf} 2$ is required for expression of HO-1, a phase 2 detoxifying and antioxidant enzyme. ${ }^{28,29)}$ Furthermore, it has previously been reported that the MAPK pathways play a regulatory role in HO-1 gene expression. ${ }^{26}$ In the present study, activation of the p38 MAPK pathway, appeared to be involved in compound 2-induced HO-1 expression (Fig. 5).

In conclusion, we demonstrated that two out of six compounds $(\mathbf{2}, \mathbf{3})$ isolated from $C$. sappan protected against glutamate-induced oxidative damage in mouse hippocampal HT22 cells. Furthermore, sappanchalcone (2) increased cellular resistance to oxidative injury caused by glutamateinduced cytotoxicity in HT22 cells, through Nrf2-dependent HO-1 expression and via activation of the p38 MAPK pathway. Based on its antioxidative effect, sappanchalcone (2) might be relevant for clinical use in pathologies where glutamate-oxidative stress is involved.

Acknowledgements This work was supported by the Korean Research Foundation Grant funded by the Korean Government (KRF-J03203).

\section{REFERENCES}

1) Kim Y. M., Kim S. G., Khil L. Y., Moon C. K., Planta Med., 61, 297-301 (1995).

2) Sasaki Y., Hosokawa T., Nagai M., Nagumo S., Biol. Pharm. Bull., 30, 193-196 (2007).

3) Oh S. R., Kim D. S., Lee I. S., Jung K. Y., Lee J. J., Lee H. K., Planta Med., 64, 456-458 (1998).

4) Niranjan Reddy V. L., Ravikanth V., Jansi Lakshmi V. V. N. S., Suryanarayan Murty U., Venkateswarlu Y., Fitoterapia, 74, 600-602 (2003).
5) Badami S., Moorkoth S., Rai S. R., Kannan E., Bhojraj S., Biol. Pharm. Bull., 26, 1534-1537 (2003).

6) Lim M. Y., Jeon J. H., Jeong E. Y., Lee C. H., Lee H. S., Food Chem., 100, 1254-1258 (2007).

7) Namikoshi M., Nakata H., Saitoh T., Chem. Pharm. Bull., 35, 36153619 (1987).

8) Ames B. N., Shigenaga M. K., Hagen T. M., Proc. Natl. Acad. Sci. U.S.A., 90, 7915-7922 (1993).

9) Maher P., Schubert D., Cell. Mol. Life Sci., 57, 1287-1305 (2000).

10) Murphy T. H., Miyamoto M., Sastre A., Schnaar R. L., Coyl J. T., Neuron, 2, 1547-1558 (1989).

11) Rössler O. G., Bauer I., Chung H. Y., Thiel G., Neurosci. Lett., 362, 253-257 (2004).

12) Coly J. T., Puttfarcken P., Science, 262, 689-695 (1993).

13) Murphy T. H., Miyamoto M., Sastre A., Schnaar R. L., Coly J. T., Neuron, 2, 1547-1558 (1989).

14) Jeong G. S., Li B., Lee D. S., Byun E., An R. B., Pae H. O., Chung H. T., Youn K. H., Kim Y. C., Biol. Pharm. Bull., 31, 1964-1967 (2008).

15) An R. B., Jeong G. S., Kim Y. C., Chem. Pharm. Bull., 56, 17221724 (2008).

16) Tenhunen R., Marver H. S., Schmid R., J. Lab. Clin. Med., 75, 410421 (1970).

17) Achenbach H., Stoecker M., Constenla M. A., Phytochemistry, 27, 1835-1841 (1988)

18) Baek N. I., Jeon S. G., Ahn E. M., Hahn J. T., Bahn J. H., Jang J. S., Cho S. W., Park J. K., Choi S. Y., Arch. Pharm. Res., 23, 344-348 (2000).

19) Namikoshi M., Nakata H., Nuno M., Ozawa T., Saitoh T., Chem. Pharm. Bull., 35, 3568-3575 (1987).

20) Shimokawa T., Kinjo J., Yamahara J., Yamasaki M., Nohara T., Chem. Pharm. Bull., 33, 3545-3547 (1985).

21) Mar W., Lee H. T., Je K. H., Choi H. Y., Seo E. K., Arch. Pharm. Res., 26, 147-150 (2003).

22) Scott K. N., J. Am. Chem. Soc., 94, 8564-8568 (1972).

23) Satoh T., Ishige K., Sagara Y., Neurosci. Lett., 371, 1-5 (2004).

24) Satoh T., Baba M., Nakatsuka D., Ishikawa Y., Aburatani H., Furuta K., Ishikawa T., Hatanaka H., Suzuki M., Watanabe Y., Eur. J. Neurosci., 17, 2249-2255 (2003).

25) Numazawa S., Ishikawa M., Yoshida A., Tanaka S., Yoshida T., Am. J. Physiol. Cell. Physiol., 285, C334 C342 (2003).

26) Kietzmann T., Samoylenko A., Immenschuh S., J. Biol. Chem., 278, 17927-17936 (2003).

27) Jeong G. S., An R. B., Pae H. O., Chung H. T., Yoon K. H., Kang D. G., Lee H. S., Kim Y. C., Planta Med., 74, 1368-1373 (2008).

28) Alam J., Stewart D., Touchard C., Bionapally S., Choi A. M., Cook J. L., J. Biol. Chem., 274, 26071-26078 (1999).

29) Jaiswal A. K., Free Radic. Biol. Med., 29, 254-262 (2000). 